\title{
Language Varieties Analysis of Dialect Differences in Bahasa Dawan
}

\author{
Yabes Olbata \\ Sekolah Tinggi Keguruan dan Ilmu Pendidikan (STKIP) Soe \\ yabesolbata@gmail.com
}

\begin{abstract}
This study aims at finding out and describing the dialect differences of Bahasa Dawan (Uab Meto) used by Timorese in Soe and how do the Timorese cope with the dialect differences when they speak the language (Uab Meto). This study used qualitative descriptive design. The participants of this study were 60 students of STKIP Soe and Soe society especially Timorese who speak Dawan fluently. The instruments used were observation and interview. The data of this study was collected through doing observation and interview. The data of this study were analyzed by using Miles and Huberman's model of analysis (Flow Model). The result of the study showed that there was difference of dialect in using Bahasa Dawan (Uab Meto) by Timorese in Soe. Based on the result of the study, it can be concluded that there was difference of dialect in using Bahasa Dawan (Uab Meto) by Timorese in Soe. Even though there was dialect difference in using Uab Meto but the society in Soe (Timorese) can cope well when they use the language to communicate with others.
\end{abstract}

Keywords: Dialect, Bahasa Dawan (Uab Meto), Timorese.

\section{INTRODUCTION}

Language is a medium of communication that allows people to share things one to another as well as to express their communicative needs (Wardhaugh, 1986). Languages are ways of expressing and recognizing the many social identities people have. They are both acquired naturally and taught formally and both natural acquisition and formal teaching create, strengthen or weaken the links between languages and identities. An important language identity link is the one between 'national language' and 'national identity'. People acquire new identities and new languages or language varieties throughout life; it is a dynamic process (Takahashi, 2000).

Language has become entrenched in human life particularly for its dominant function in communication. In a society, we find different languages and dialects to represent the speakers' native place. Every country has its own standard language with a number of dialects which are different. They have their own lexicon, grammar and culture. Language conveys meaning through the content of words and sentences, and this kind of meaning has been a traditional object of study in the field of language acquisition. However, language also provides meaningful information beyond the content which indexes social properties of the speaker and the speech situation. For example, people from different geographical regions talk differently, even when they are speakers of the same language. These differences have been extensively studied by linguists and prominently include systematic differences in the phonological systems and differing conditioning environments for various phonological rules, such as final consonant deletion (e.g., Labov, 1972; Preston, 1993; Trudgill \& Hannah, 2002).

In social life, language is used according to the situation and context where the communication takes place. In a formal situation, people use standard language, written or oral, while in informal situation informal language. The choice of language as such deals with who speaks, what topic, what language, to whom, when and to what end (Fisherman in Chaer, 2006). Thus, people must be able to select the appropriate words or sentences to communicate with the others in certain situation while considering about the background of the listener, the language he/she uses to speak, the topic of the conversation, so that the words and sentences the speaker uses are more acceptable for the listener. The use of language in social life is being the symbol of culture of certain social groups, as stated by Bright in Baghi (2008) that, a language is used in social group, directly reflects the culture or as the symbol of culture. In this case, the use of language as the symbol of culture deals with the function of language to show the characteristics of an ethnic group who has the same interpretation and speaks the same standard language in their daily communication.

It is clear that language is an important part of human's life because only through language people can communicate to share their ideas and interests. However, every place has its own dialect that becomes the original identity as the society and member of that group. In this study, the researcher wants to find out the dialects differences of Bahasa Dawan used by Timorese (Mollo, Amanuban, and Amanatun) when they use Bahasa Dawan as the tool in communication and how do the Timorese cope with the differences problem when using the language.

Every language that is spoken over any significant area is spoken in somewhat different forms in different places; these are its regional dialects. The study of regional dialects, known as dialect geography, has been a major part of linguistics since the late nineteenth century; there have been many studies of regional variation, often resulting in the publication of dialect atlases containing a series of dialect maps, each showing the variation in respect of a single feature. Linguistically, unsophisticated people sometimes apply the term dialect to a regional language of low prestige, but the term is never used in linguistics, in which a dialect is always a variety of language which has other varieties. The purpose of language is to represent the nature and the culture of the society. In society, on every step of life, language is required 
to fulfill the essential needs of life or to identify the living and non-living things in this world.

\section{METHODS}

The design of the research was a form of qualitative research because the focus was on describing and explaining the differences of dialect in Bahasa Dawan used by Timorese in Soe and the way Timorese cope with it when they speak using the language with people who used different dialect from these three tribes. Cresswell (1994) stated that one of the purposes of qualitative research is to understand the participants' point of view of the events, situation and action that they are involved and of the explanation that they give about their lives and experiences. This study was conducted in Soe and the participants were 60 students of STKIP Soe and the Soe society who could speak Bahasa Dawan well. As argued by Creswell (1994), data collection steps involve setting boundaries for study, collecting information through observation, interviews, documents, visual materials and establishing the protocol for recording information. To obtain the data for this study, there were two kinds of instrument used. The instruments were observation and interview.

\section{FINDINGS AND DISCUSSIONS}

After doing the observation for three months in STKIP Soe and the Soe society, the result of the observation on the dialect differences of Bahasa Dawan consist of verbs, adjectives, adverbs and nouns that became the main differences of dialect between the three tribes (Mollo, Amanuban and Amanatun) Soe who speak Bahasa Dawan as the mother tongue or native language in Soe. .

The result of the observation was divided into some categories such as; verbs, nouns, adjectives and adverbs. The first category was the verbs which were presented as below:

Table 1. List of verbs of the three tribes (Mollo, Amanuban and Amanatun)

\begin{tabular}{|c|c|c|c|c|}
\hline \multirow{2}{*}{ 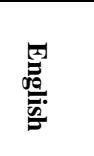 } & \multirow{2}{*}{ 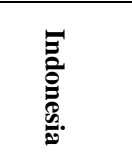 } & \multicolumn{3}{|c|}{ Dawan } \\
\hline & & \multirow[t]{2}{*}{ Mollo } & \multirow[t]{2}{*}{ Amanuban } & \multirow[t]{2}{*}{ Amanatun } \\
\hline Verbs & $\begin{array}{c}\text { Kata } \\
\text { Kerja } \\
\end{array}$ & & & \\
\hline See & Lihat & Ail & Kius/'nu/kios & U'et \\
\hline Eat & Makan & Euk/eok/uah & Uah/euk & Eok/euk/ua \\
\hline Want & Mau/Ingin & Loim/loem/sinmak & Loim & He/loem \\
\hline Go & Pergi & Ael/nao/na'o & $\mathrm{Nao}$ & Nao/fain/meu \\
\hline Ask & Tanya & Toit/toet & Utan/toit & Utan \\
\hline Try & Coba & Soba & Soba/msu & Soba/mutaka \\
\hline \multicolumn{5}{|c|}{$\begin{array}{l}\text { Table 2. List of nouns of the three tribes (Mollo, } \\
\text { Amanuban and Amanatun) }\end{array}$} \\
\hline Nouns & $\begin{array}{c}\text { Kata } \\
\text { Benda }\end{array}$ & Mollo & Amanuban & Amanatun \\
\hline Girl & Gadis & Bifel & Bisopo/lifeto/bino & Bife/binon \\
\hline Market & Pasar & Pasa & $\mathrm{n}$ & munif \\
\hline Troubl & Kesulita & Suspok/stembo & Soba & Basak/'mas \\
\hline $\mathrm{e}$ & $\mathrm{n}$ & $\mathrm{k}$ & U'nenu/us'unu & a \\
\hline Scar & Bekas & Fiki/pap balaf & Biki/nu'e balan & Usus \\
\hline Shirt & luka & Sebalu/sebaul & Fanu & bok/unenu \\
\hline & Baju & & & $\begin{array}{l}\text { Fiki/takaf } \\
\text { 'noso }\end{array}$ \\
\hline
\end{tabular}

Table 3. List of adverbs of the three tribes (Mollo, Amanuban and Amanatun)

\begin{tabular}{|c|c|c|c|c|}
\hline Adverbs & $\begin{array}{c}\text { Kata } \\
\text { Keterangan }\end{array}$ & Mollo & Amanuban & Amanatun \\
\hline $\begin{array}{l}\text { Over } \\
\text { there }\end{array}$ & Disebelah sana & Panin & $\begin{array}{l}\text { Pai na } \\
\text { Kle nut }\end{array}$ & Aom bian \\
\hline Two & Hari ini & Kle nub & Neon i & Klei nua \\
\hline weeks & Disini & Neon ij & Es i & Neon le'i \\
\hline Today & Banyak kali & Es ije & Tenim- & Es ai \\
\hline Here & Saat ini & Piut-piut & teni/nao & Na'et \\
\hline Many & & Tabu ije & Es la'i/tabu i & piut \\
\hline times & & & & In la'i \\
\hline This time & & & & \\
\hline
\end{tabular}

Table 4. List of adjectives of the three tribes (Mollo, Amanuban and Amanatun)

\begin{tabular}{lllll}
\hline & & & & \\
& & & & \\
& Kata & \multicolumn{1}{c}{ Mollo } & Amanuban & Amanatun \\
& & & & \\
\hline Beautiful & Cantik & Namasan fin & Masankah/mas & Namas nis \\
Full & Kenyang & Umsen/namsen & le'uf & Pet \\
Loudly & Keras & Nahel & Pet & Nhunun/koa \\
Fluent & Lancar & Kan manoef & Namep & Laleok \\
Expensive & Mahal & Maneone & Kan a'ef & Nae le'uf \\
Brave & Berani & Balain & Mafena & balani \\
& & & Men & \\
& & & le'uf/manenu & \\
\hline
\end{tabular}

Based on the observation result, it could be seen that the Timorese in Soe spoke the same language but in different dialect. The dialect used by the Timorese when they speak Bahasa Dawan (Uab Meto) can be divided into three types according to three tribes who lived in Soe which were Mollo, Amanuban and Amanatun. In daily life, Soe people used Bahasa Dawan (Uab Meto) which is their mother tongue to communicate with others. But in the communication they have slight differences in the dialect they used because each tribe used their own dialect in using the language (Uab Meto). It also happened because of the difference of regional dialect. The difference of dialect in Bahasa Dawan (Uab Meto) among these three tribes was found on the form of word, letter or spelling, accent and intonation.

The result of the observation was similar to the result of interview which was done by the researcher in order to get more data towards the dialect differences of Bahasa Dawan (Uab Meto) used by Timorese people in Soe which consist of three tribes namely Mollo, Amanuban and Amanatun. After interviewing the participants, then the result of interview showed that the dialect of Bahasa Dawan (Uab Meto) use by Timorese in Soe was different from one tribe to others which meant that there was difference between Mollo, Amanuban and Amanatun. In response to the questions related to the dialect differences of Bahasa Dawan (Uab Meto) used as tools of daily communication, the participants stated some reasons that make them felt proud of using their own dialect when speaking Bahasa Dawan (Uab Meto).

Looking from the observation result and also from the interview result, it was clear that there was differences of 
dialect of Bahasa Dawan (Uab Meto) used by Timorese in Soe when they speak using the language. The differences lied on some factors that could be seen on the tables in the finding's part. Even though the Soe society used only Bahasa dawan (Uab Meto) as their mother tongue to communicate each other, but there was differences of dialect in using Bahasa Dawan (Uab Meto). The first factor that supported the dialect differences among these three tribes (Mollo, Amanuban and Amanatun) in using Bahasa Dawan (Uab Meto) as their mother tongue was on the form of words. It was clear that in some words of Mollo dialect were different from Amanuban and Amanatn dialect (eq; "Market" 'masa' (Mollo), 'soba' (Amanuban), 'pasak' (Amanatun). Sometimes the words were totally different but sometimes not. The second factor of the dialect differences between these three tribes was found in the form of letters or spelling (eq: "Diligent", 'makoe' (Mollo), 'nmakoe' (Amanuban), 'makoene' (Amanatun). Another factor that supported the dialect differences in using Uab Meto as the language in Soe society was in the form of accent. This factor could be found when the people of these three tribes were speaking. Each tribe would use their own accent according to their tribe. It also could happen when they were speaking to people from different tribe. The last factor that supported the dialect differences among these three tribes was the intonation. The intonation of each dialect was different and it could be seen when they were speaking the language (Uab Meto).

Besides stating the result of the observation, then the result of interview was also stated in order to support the data about the dialect differences of Bahasa Dawan (Uab Meto) used by Timorese in Soe. In responding to the interview questions, the participants of these three tribes stated some main reasons of dialect differences of Uab Meto that becomes their mother tongue in everyday life and how do they cope with this dialect differences problems. The first point stated by the participants was that they always use their own dialect when they speak to others even when they speak to people from other tribes. By using their own dialect (Mollo, Amanuban and Amanatun) they could also show their real identity. In addition to that, the participants also stated that the dialect they have was something which could not be separated from their life so it was hard for them to speak using another dialect. The second point stated by the participants was that they always felt proud of using their dialect even though it was different from others. In responding to the third point about the ways done to understand the dialect differences when they speak Uab Meto, the participants stated that there was only slight difference of dialect from these three tribes so it was not really difficult to be understood. The participants also added that they tried to adapt themselves based on the situation when they were speaking to people from different tribe so that they could understand what was they were talking about even though sometimes they found small difficulties because of the dialect differences but it was not really a big problem for them.

To respond the question related to the dialect changes when they make friends with people that use different dialect, some participants stated that there was no change of dialect because they only tried to adapt with the context of situation. But some participants stated that sometimes there was a little change in dialect they used because they tried to be closer to the people they were talking too but it only happened in a short time, so when they speak to people with the same dialect then they will use their own dialect as usual. They also stated that the use of dialect difference could not be avoided since they live together with other people who speak different dialect, but it did not mean that by living together in a particular place then it could make them to change their own dialect or even leave their own dialect. It could be seen by the responds of the participant in which most of the participants stated that sometimes they felt hard to cope with the problem of dialect differences in using Bahasa Dawan (Uab Meto) when they speak to their friends because it happened naturally and continuously in their life. Even though they faced that kind of problem but they tried to use their own dialect when they speak to their friend and it could be the reason for them to change their own dialect.

To respond the question related to the way the participants adapt with their friends or people who speak different dialect from them, the participants said that they actually could adapt well because the dialect difference was not a measurement for them to life apart from the other people who speak different dialect (Uab Meto). They also said that the dialect difference was not a big problem for them or as a hindrance in building communication because they believed that the dialect difference was a good way for them to learn more about the language (Uab Meto). It helped them to assimilate with other people who speak different dialect with them.

The last question on how to cope with the dialect differences in using the language (Uab Meto) was still related to the way of adaptation in which tried to find out how did the adaptation happen between the user of Bahasa Dawan (Uab Meto), it could be found that the participants gave similar respons tto this question by stating some point such as; some participants stated that they had to insist themselves to adapt with those who speak different dialect because they never meet people who speak different dialect in Bahasa Dawan (Uab Meto) that tried to adapt with them. They added that it was hard because sometimes they felt that they were not accepted to be friends but it did not mean to make them felt shy to speak using different dialect. Some participants stated that they would try to see the situation around before having the communication. When they saw that their interlocutors were people who speak different dialect then they have to find the way of how to cope with them. Sometimes they had to adapt with the situation in order to make the conversation more understandable. They also stated that sometimes they need to force themselves to be the part of the people who speak different dialect because they thought that the dialect differences was not a really problem to stop their relationship in relation to the use of language (Uab Meto). While some participants stated that it depended on the situation in which when the people from different dialect of Bahasa Dawan (Uab 
Meto) visit them, then the visitors need use the dialect of the participants but when the participants visited the people of different dialect then participants need to speak using the host (people from different dialect) dialect. In addition to that the participants response on the issues of the dialect differences in using Bahasa Dawan (Uab Meto) it can be concluded that the participant can cope with the dialect differences well

\section{CONCLUSION AND SUGGESTIONS}

From the result of observations, it could be seen that there was dialect differences of Bahasa dawan (Uab Meto) used by Timorese in Soe. Besides that, it could be seen that the dialect difference was in the form of words, letters (spelling), accent and intonation. Even though there was difference in dialect of Bahasa Dawan (Uab Meto), it was also the similarities in some words and letters (spelling). There was completely difference on accent and intonation when the people of Soe speak using the language.

In line with the result of the observation, it could be seen on the result of interview also that even though there was difference of dialect in Bahasa Dawan (Uab Meto) when the Timorese in Soe speak using the language, they could understand well when the communication happened between them. In addition, the people of Timor in Soe did not make the dialect difference as a big problem that could separate them. The people also did not influence by the dialect difference because even though they have different dialect when they speak to each other they were proud to use each of their own dialect.

From the portrait of observation and interview result, there were some suggestions to the Timorese people, especially Soe society who speak Bahasa Dawan (Uab Meto) in difference dialect to adapt well when having conversation with others who speak different dialect. The Timorese also need to understand the dialect difference so it could not be a problem in speaking using Bahasa dawan (Uab Meto). The Timorese have to aware of dialect difference in using Bahasa dawan (Uab Meto) and make it as an interesting thing that shows their identity.

\section{REFERENCES}

Baghi, Y.G.D. (2008). Social Meanings of Sar Tambung In the Speech Community of Cila Dialect: A Sociolinguistic Analysis. Unpublished Thesis. Kupang. FKIP- Undana.

Chaer, A. (2006). Telaah Semantik. Jakarta. Rineka Cipta.

Creswell, J. W. (1994). Research design: Qualitative and quantitative approaches. Thousand Oaks, CA: SAGE

Labov, W. (1972). Sociolinguistic patterns. Philadelphia : University of Pennsylvania Press.

Preston, D. R. (1993). American dialect research. Philadelphia: John Benjamins.

Takahashi, H. (2000). Dealing with dealing in English: Language skills for Japan's global markets (Report 7A). Washington, DC: Japan Economic Institutue..
Trudgill, P. W. \& Hannah, J. (2002). International English: a guide to the varieties of standard English. London: Arnold.

Wardhaugh, R. (1986). .An introduction to sociolinguistics. The UK: Blackwell 